\title{
Human capital development in
}

\section{socio-economic malaise: evidence from}

the UK

\section{Nawaz, T}

http://hdl.handle.net/10026.1/9654

\subsection{4/IJLIC.2017.080640}

International Journal of Learning and Intellectual Capital

All content in PEARL is protected by copyright law. Author manuscripts are made available in accordance with publisher policies. Please cite only the published version using the details provided on the item record or document. In the absence of an open licence (e.g. Creative Commons), permissions for further reuse of content should be sought from the publisher or author. 


\title{
Human capital development in socio-economic malaise: evidence from the UK
}

\author{
Tasawar Nawaz \\ Plymouth Business School \\ University of Plymouth \\ Plymouth \\ PL4 8AA \\ United Kingdom \\ Email: tnawaz@plymouth.ac.uk
}

\begin{abstract}
The purpose of this paper is to provide a novel insight into the role of knowledge-resources, particularly human capital, in times of socio-economic distress using a qualitative research approach. This is required because the social and economic environment has been transformed significantly in certain regions such as Europe since the global financial crisis humped in the fall of 2008. The study reveals how knowledge resources interact in building knowledge-eco society, how human intellectual capital thrives under tough economic conditions, and how human capital may help an economy to sustain its fiscal position.
\end{abstract}

Keywords: $\quad$ knowledge resources; human capital; austerity; socio-economic distress; social welfare; United Kingdom.

\section{Introduction}

Europe is the land of redistributive policies (Nawaz, 2015). Explicitly, with the aim of promoting social inclusion, it devotes to social policies a larger fraction of GDP than any other continent (Boeri, 2010). A burgeoning concern in the public debate, however, is driven by the fear that migrants are fiscal burden because they drain public resources by drawing on the generous social transfers introduced in Europe to prevent social exclusion (see Boeri, 2010; Drinkwater and Robinson, 2013; Dustmann and Frattini, 2014). Such worries are also reflected in the 2008 European Social Survey in which only 8\% of the participants agreed that immigrants should have access to social benefits. Politicians also support such beliefs and urge policy makers to restrict welfare access for the immigrants (Boeri, 2010). In the UK, government recently announced a 12 billion pounds welfare cuts to tackle tenuous fiscal imbalance. The move is equally aimed as to tackling the abysmal migration inflows from the European Union (EU), in which many Europeans targeted the UK's exchequer as an easy 
scapegoat within Europe. One of the main reasons behind migration within EU is the financial crisis that has put the financial markets in the midst of a credit crisis of historic breadth and depth in the fall of 2008 (Campello et al., 2010) is still engulfing many economies within the EU. Europe has imposed new economic policies, i.e. austerity to reduce the government budget deficit that is posing an additional threat to social welfare programs across Europe. This equally has urged many skilled and unskilled individuals to migrate to markedly more resilient economies within Europe such as Germany and United Kingdom.

Paradoxically, the empirical evidence suggests that immigrants being EU or non-EU domiciled add higher fiscal contribution by working longer hours, paying consistent taxes, and bringing skills which UK may lack (Rowthorn, 2008; Liebig and Mo, 2013; Dustmann and Frattini, 2014). This suggests that UK provides a rich social and economic environment in which the migrants (human capital) flourish and ultimately add value to the exchequer. It is thus surprising that there is no stark evidence that presents substantive evidence on the thriving capabilities of human capital in Europe at times of socio-economic distress ${ }^{1}$.

The existing literature mainly focuses on the impact of immigration on native workers' wages and their employment (e.g., Ottaviano and Peri, 2012; Manacorda et al., 2012; Dustmann and Frattini, 2014), which tends to ignore the thriving capabilities of knowledge resources such as human capital in socio-economic malaise. The present study therefore, explores the role of human capital from a novel prospect socio-economic setting in the context of non-UK domiciled residents. Based on interviews with diversified ethnic groups while using the lens of social capital theory, the study reveals how knowledge-resources i.e. human capital thrives in social settings in times of socio-economic turbulence and even adds value to a country economy. The study finds that migrants bring along various profiles of intellectual capital to the UK, however the human capital (i.e. knowledge, skills, expertise) of these migrants is underutilized as most of them are in jobs other than their areas of expertise with lower wages. Notwithstanding, migrants from EU countries bring more knowledge and skills into the UK, which ultimately built and nourish a socio-eco-society and to help reduce the fiscal burden of the country. At times when economies and establishments around the globe are shrinking and causing economic and social distress, it provides an equal

\footnotetext{
${ }^{1}$ Economic distress is triggered by financial distress, which refers to the condition where an individual firm or state is unable to meet its financial obligations to its creditors. Economic stress is plenty of anxiety around all the economic actors. For instance, firms lament stagnating or falling sales while entrepreneurs hold back their investments, fearing from inadequate returns. Ultimately, the stress is passed onto the individual employees as they fear losing their jobs since they witness increased chance of bankruptcy. As a consequence, morale amongst workers goes down while stress goes up, which results in lower productivity. This is when one's social life is disrupted, the social distress.
} 
opportunity for human capital to flourish further. Thus, knowledge assets i.e. human capital does not depreciate in time of economic meltdown, instead it thrives, given appropriate social settings.

The paper is organized as follows. Section 2 discusses the background of the study and marries the concepts of intellectual capital and social capital theory. Sample description and profiling of research participants is summarized in Section 3 while Section 4 discusses the results and the final section concludes the study.

\section{Background}

\subsection{Economic turmoil and migration in Europe}

Financial turmoil and huge government deficits are two fundamental tendencies that engendered the longest recession of recent time (Peet, 2011). Although the reckless speculations of the small and powerful financial capitalist elite caused the crisis, the neoliberal states of Europe have reacted by imposing societal punishment in the form of fiscal austerity on the hard-working tax payers instead (Taylor-Gooby and Stoker, 2011). Such fiscal retrenchment has provoked social and economic distress across Europe (for further details, see Ponticelli and Voth, 2011; Clarke and Newman, 2012). The downward hysteretic shift in the region's growth path turned worsen the already blead fiscal situation (Howden, 2011) and ultimately gave rise to unemployment ${ }^{2}$ and equally urged many skilled and unskilled individuals to migrate to markedly more resilient economies such as Germany and United Kingdom. Germany although possesses superior economic performance yet, hinders for German language as a significant factor holding such human capital inflows. Given an advantage of English as international language, UK has become the epicenter for EU immigrants. Furthermore, EU nationals can exercise their EU-treaty rights, including access to the British welfare state upon passing the habitual residency test ${ }^{3}$.

The economic 'push-pull' theory of migration (King, 2012) is found to offer a better option that takes into account the idea of utility maximization. That is to say, an underlying assumption for migrants to seek out employment in another country (in this case, the UK) will be based on perceived 'push' factors in their home country (the EU countries, in this

\footnotetext{
${ }^{2}$ According to the recent estimates of Eurostat (2015), an estimated 23.35 million people in the EU are unemployed. Among the member states, the highest unemployment rates were recorded in Greece (25.6\%) and Spain $(22.5 \%)$ and the lowest in Germany (4.6\%) and the UK (5.6\%). Last ten years unemployment rates are summarised in appendix 2.

${ }^{3}$ See Kennedy (2011) for further details.
} 
case), such as socio-economic unrest, lack of employment opportunities as well as 'pull' factors in the prospective host country, such as increased societal support and employment opportunities. Academics however, have reacted by providing the empirical evidence on the economic consequences of immigration and have ignored the thriving capabilities of knowledge-resources such as human capital at times of economic and social distress.

\subsection{Intellectual capital}

Generally, intellectual capital meant more than just 'intellect as pure intellect' but rather incorporated a degree of 'intellectual in action' (Hudson, 1993). In that sense, IC is not only a static intangible asset per se, but an ideological process. It is the kind of movement from 'having' knowledge i.e. often referred to as human capital and skills to 'using' the knowledge and skills i.e. often referred to as intellectual property in Stewart and Ruckdeschel (1998) that is captured in a circuitous way in literature. Knowledge resources are often referred to as implicit (tacit) or explicit (codified). The former is embedded in individuals and inseparable from its barrer (Davis, 1967) whereas the later steams of knowledge in Nonaka and Takeuchi (1995) is transferable in formal, systematic language e.g. via reports, and databases (also see Crane, Bontis, and Chase, 2014).

Stewart and Ruckdeschel (1998) posit that every business relies increasingly on knowledge and old-fashioned experience. Added together, this knowledge is intellectual capital and it can be defined as the sum of everything everybody in the company knows that gives you a competitive edge in the market. Sveiby (1997) described IC as the knowledge, experience, employee intellect and knowledge resources stocked up in an organization's databases system processes, culture and philosophy. IC is further divided into various subcomponents. At the same time while the terms used to describe intellectual capital are different, they basically refer to: human capital: the knowledge embedded in people; structural capital: the knowledge embedded in the organization and its systems; and relational capital: the knowledge embedded in customers and other relationships external to the organization (Guthrie et al., 2012; Dumay and Garanina, 2013). To synthesize, there is a broad consensus that IC contains human IC, structural IC, and relational IC (Brooking, 1996; Stewart and Ruckdeschel, 1998; Nawaz and Goj, 2013; Pablos, 2003; Sveby, 2007). These three forms of IC work together (Stewart, 1997) in order to enable a company to transform its knowledge and skills into competitiveness and wealth (Edvinsson and Malone, 1997; Rylander et al., 2000). 


\subsection{Intellectual capital research}

Intellectual capital research has evolved over the past two decades in what Guthrie et al. (2012) described as three distinct stages with Dumay and Garanina (2013) adding the fourth stage of IC research being IC eco-systems. A chronological review of major IC practice and research milestones is provided in Table 1.

Table 1 Distinct Stages of IC Research

\begin{tabular}{|c|c|c|}
\hline Stages & Milestones & Question Explored \\
\hline Stage 1 & $\begin{array}{l}\text { The first stage of IC research has its origins in the late 1980s and } \\
\text { into the } 1990 \text { s. First-stage efforts have typically focused on } \\
\text { consciousness raising activities that strive to communicate the } \\
\text { importance of recognizing and understanding the potential of } \\
\text { intellectual capital in creating and managing a sustainable } \\
\text { competitive advantage. }\end{array}$ & What is IC? \\
\hline Stage 2 & $\begin{array}{l}\text { The second stage of IC research can be defined as a stage where } \\
\text { approaches to measuring, managing and reporting IC came to the } \\
\text { fore and to gather evidence in support of its further development. } \\
\text { During this stage several classifications of IC have been provided } \\
\text { resulting in the identification of three main IC components and } \\
\text { related elements. While these components may have different } \\
\text { names, they basically refer to: Human IC, Structural IC and } \\
\text { Relational IC }\end{array}$ & $\begin{array}{l}\text { How to make } \\
\text { invisible (IC) assets } \\
\text { visible? }\end{array}$ \\
\hline Stage 3 & $\begin{array}{l}\text { A third stage of IC research that emerged since the mid-2000s is } \\
\text { characterized by research critically examining IC in practice, } \\
\text { devoted to the managerial implications of how to use IC in } \\
\text { managing a company. }\end{array}$ & How is IC utilized? \\
\hline Stage 4 & $\begin{array}{l}\text { Dumay and Garanina (2013) have toyed with the idea of a fourth } \\
\text { stage of IC research based on IC eco-systems of cities and nations to } \\
\text { complement (not oppose) the third stage of IC research. The third } \\
\text { stage of IC concentrates on building strong organizations, while the } \\
\text { fourth stage concentrates on building strong economic, social and } \\
\text { environmental eco-systems, where healthy organizations can } \\
\text { flourish. Although the idea is fairly appealing, yet, the dilemma is } \\
\text { that it might be applicable to developed economies whereas } \\
\text { developing economies are still not prone to the idea of IC in its full } \\
\text { capacity. Therefore, a lot needs to be achieved before reaching the } \\
\text { imaginary Stage } 4 \text { of ICR. }\end{array}$ & $\begin{array}{l}\text { How to build a } \\
\text { strong IC eco- } \\
\text { system for } \\
\text { organizations? }\end{array}$ \\
\hline
\end{tabular}

Sources: Adopted from Guthrie et al. (2012) and Dumay and Garanina (2013)

The field of IC has experienced various evolutionary stages. Initially, the concept of IC was created for updating the understanding of the competitive advantage of business in knowledge-intensive, rapidly changing business environment (Stahle and Hong, 2002). From early stage between 1990s to early 2000 IC research remained focused on defining the fundamental concept of IC (Sullivan, 1999) whereas the second stage of IC research in Guthrie et al. (2012) began with the new millennium. It was when various approaches to 
measuring, managing and reporting IC came to the fore and to gather evidence in support of its further development. Since then a shift in the business environment from the Industrial Age to the Information Age (Hsu and Wang, 2012) have been felt.

Traditionally research on IC has remained focused on high-tech industries such as IT (e.g., Wang and Chang, 2005; Chang, 2007; Seleim et al., 2007); biotechnology (Hermans and Kauranen, 2005; Sharabati et al., 2010; Pal and Soriya 2012); manufacturing ( Camuffo and Comacchio, 2005; Tseng and Goo, 2005; McConnachie, 1997); and the service industry such as banks (Murthy and Mouritsen, 2011; Mention and Bontis, 2013; Kamath, 2007; Goh, 2005; Curado, 2008). These studies identify IC as one of the key drivers of firm-level performance (Teece, 1998; Youndt et al., 2004; Martínez-Torres, 2006; Rudež and Mihalič, 2007).

It is not to say that these studies are not of paramount importance, quite the contrary. These scholarly efforts exposed the intangible concept of IC to those orthodox academics, practitioners, policy makers, and other related commentators and made them realize the fact that in today's knowledge-intensive era value creation process requires both tangible resources in the form of physical and financial assets and intangible resources i.e. IC. Although Dumay and Garanina (2013) have proposed the IC eco-systems for organizations and nations (see Table 1) however, only a scant attention has been paid to how intellectual capital on individual level is created and flourished.

Nahapiet and Ghoshal (1998) have observed that social capital facilitates the creation of new knowledge whereas Coleman (1988) suggests that social ties facilitate the creation and flourishing of human capital. In this view, social bounds assist people to exploit their personal intellectual capital further by learning in a social environment. In other words, the social environment provides individuals a platform to exploit their personal intellectual capital and equally benefits the societal groups at large. Hence, social bounds play a pivotal role for the development of new knowledge and skills. Given the significant effect of recent financial crisis, which has caused not only economic distress but social distress as well, the role of knowledge resources i.e. human capital in times of such turbulence is worth testing.

\subsection{Social capital}

Hauberer (2011, p. 50) defines social capital 'as resources embedded in relationships among actors'. Coleman (1988, p. 101) further clarifies that social capital is 'less tangible yet, for it exists in the relation among persons', indicating that social capital is something of intangible in nature, putting it close to the conceptual roots of intangibles or simply IC. Embedded in his 
theory of praxis, Bourdieu (1986) developed the concept of social capital. In his view social capital is strongly connected to different societal fields which in turn are places for the social praxis of actors. Accordingly, social capital cannot be seen as freestanding. Bourdieu (1986, p. 245-9), therefore 'distinguishes different types of capitals:

Economic capital: capital than can be converted into money immediately and directly. But it also exists in the institutionalized form of property rights. From an IC standpoint, economic capital refers to financial capital and structural capital.

Cultural capital: Cultural capital exists in three different states. It can be internalized/ incorporated, objectified or institutionalized. Cultural capital is incorporated as durable qualities of an individual such as knowledge or skills. Cultural goods, like paintings, books, etc. are an objectification of cultural capital, and institutionalized cultural capital appears as scholastic sanctioned titles, like diplomas. In this sense, from an IC lens cultural capital mainly refers to human intellectual capabilities.

Social capital: the aggregate of the actual or potential resources which are linked to possession of a durable network of more or less institutionalized relationships of mutual acquaintance and recognition or in other words, membership in a group which provides each of its members with the backing of the collectively owned capital, a 'credential' which entitles them to credit, in the various senses of the word.

Table 2 Main Conceptual Approaches of Social Capital

\begin{tabular}{|l|l|l|}
\hline $\begin{array}{l}\text { Social capital } \\
\text { approach }\end{array}$ & Main ideas & Relevant contributions \\
\hline $\begin{array}{l}\text { Economic } \\
\text { development } \\
\text { theories }\end{array}$ & $\begin{array}{l}\text { Confidence, civic behavior and associativity } \\
\text { tostrengthen the social networks, contributing } \\
\text { to the sustainable economic development }\end{array}$ & $\begin{array}{l}\text { Putnam (1994); Knack and Keefer } \\
\text { (1997); Stiglitz (1998) }\end{array}$ \\
\hline $\begin{array}{l}\text { Social } \\
\text { responsibility } \\
\text { and } \\
\text { ethics }\end{array}$ & $\begin{array}{l}\text { Social capital expresses the degree of social } \\
\text { integration and responsibility with respect to } \\
\text { the whole society and its agents and groups. It } \\
\text { is based on values and attitudes, such as } \\
\text { confidence, cooperation, safety, principles, } \\
\text { ethics, compromise and ethics }\end{array}$ & $\begin{array}{l}\text { Coleman (1990); Newton (1997); } \\
\text { Chang (1997); Kawachi et al. } \\
\text { (1997); Bullen and Onyx (1998); } \\
\text { Joseph (1998); Cortina (2000); } \\
\text { Baron (2001) }\end{array}$ \\
\hline $\begin{array}{l}\text { Corporate } \\
\text { governance }\end{array}$ & $\begin{array}{l}\text { Ethics and corporate governance codes have a } \\
\text { positive impact on the creation of social } \\
\text { capital, stimulating the solidarity and } \\
\text { overcoming market imperfections }\end{array}$ & $\begin{array}{l}\text { Baas (1997); Sen (1997); Zingales } \\
\text { (2000); Rajan and Zingales (2000) }\end{array}$ \\
\hline $\begin{array}{l}\text { Intellectual } \\
\text { capital }\end{array}$ & $\begin{array}{l}\text { Social capital is a component of IC. It is based } \\
\text { on a set of values and the subsequent } \\
\text { indicators such as confidence, loyalty, } \\
\text { sincerity, compromise, transparency, } \\
\text { solidarity, responsibility, honesty and ethics }\end{array}$ & $\begin{array}{l}\text { Nahapiet and Ghoshal (1996); } \\
\text { Koening (1998); Prusak (1998); } \\
\text { Lesser and Prusak (1999); Lesser } \\
\text { (2000); Cohen and Prusak (2001); } \\
\text { Kenmore (2001); Lesser and } \\
\text { Cothrel (2001); McElroy (2001) }\end{array}$ \\
\hline
\end{tabular}

Source: Bueno et al. (2004) 
Various conceptual approaches of social capital have been documented in the literature over the years. A summary of the main approaches is provided in Table 2. Hauberer (2011, p. 42-5) further simplifies that there are different kinds of social capital such as (i) relations of mutual trust: A relation of mutual trust exists, if actor A does something for actor B and trusts B to reciprocate in the future. This action establishes an expectation in A and the obligation in $\mathrm{B}$ to justify the trust. This obligation corresponds to a 'credit slip' that is possessed by A and can be redeemed by some performance of B. Many 'credit slips' constitute a large body of credit an actor can draw on, if necessary. For this kind of social capital the trustworthiness of the social surroundings (the probability that obligations are redeemed) and the amount of outstanding obligations are of special importance; (ii) authority relations: If actor A (in this case a beneficiary of social benefits) transfers the rights of control of a specific action to actor B (the benefit awarding body), an authority relationship comes into being. In this case, actor B possesses social capital in the form of rights of control; (iii) informal potential: Social relationships contain an information potential or the capability to provide its members with information helpful in the utility maximization process; (iv) effective norms: Effective or prescriptive norms are a powerful, but also fragile kind of social capital. A prescriptive norm is very important in a collective. It enjoins an actor to espouse a certain behavior in the interest of the collective and prevents this actor from behaving in his/her own interests; and (v) appropriable social organizations: voluntary or not-for-profit organizations are all those establishments that provide social capital by producing public goods.

Bueno et al. (2004, p. 557) note that social activities have an eminent role in the knowledge-based economy. They are a set of critical resources that enable the creation of essential competences. Moreover, social activities increase the capacities for the creation, sharing and management of knowledge generating sustainable competitive advantages. The authors further summarize the conceptual approaches of social capital (see Table 2). This study attempts to merge the concept of social capital with intellectual capital in determining the role of intellectual capital in times of socio-economic distress.

\section{Research methodology}

The after effects of the recent financial meltdown can still be felt in various parts of the world and Europe in particular. In most recent events inclusion of Romania and Bulgaria into the European Union on the new year eve 2014, the economic instability in Portugal, Spain, Greece, Italy, and to a lessor extent in France are all those potential factors which played a 
vital role in sky-high unemployment rates in these countries, causing social and economic distress within the societies. A summary of selected economic indicators from European counties are provided in Table 3. This socio-economic turmoil has urged many skilled and unskilled individuals to migrate on temporary basis to safe heavens. Given the advantage of English as international language UK is the ultimate destination for many within Europe and beyond. Furthermore, according to the EU treaty, EU residents are entitled to claim and exercise their treaty rights which include access to public funds via unemployment benefits, housing allowance, job seeker allowance, working tax credits, childcare benefits schemes and free healthcare. This is one the major problems facing the current UK government and to counter this problem the current conservative UK government has tightened its immigration policy particularly 'for routes where abuse was rife while still encouraging the brightest and best to come here to study and work' (Dustmann and Frattini, 2014).

In contrast, many recent surveys and published reports (i.e., Dustmann and Frattini, 2013; Rowthorn, 2008; OECD, 2013); suggest that immigrants being EU or non-EU residents add value to the UK economy by working longer hours, paying consistent taxes, and bringing skills which UK may lack. OECD (2013, p. 10) suggests that 'most immigrants do not come for social benefits, they come to find work and to improve their lives and those of their families, employment is a better way to do this than the dole'. Likewise, Dustmann and Frattini (2013, p. 27) find that 'the contribution of recent immigrants (i.e. those who arrived after 1999) to the UK fiscal system, however, has been consistently positive and remarkably strong. Between 2001 and 2011 recent European Economic Area (EEA) immigrants contributed to the fiscal system $34 \%$ more than they took out, with a net fiscal contribution of about 22.1 billion GBP. In contrast, over the same period, natives' fiscal payments amounted to $89 \%$ of the amount of transfers they received, or an overall negative fiscal contribution of 624.1 billion GBP'. Given this evidence, the government claims about 'benefit tourism' by EU immigrants seem to be disconnected from reality.

Before moving further, it is imperative to put the economic conditions of selected countries at glance. Focusing first on the population figures reported in the second column of Table 3, a high diversity can be observed. Germany is leading in absolute number of current population with 81 million inhabitants whereas Bulgaria is at the bottom of the table with 6.9 million and total population of UK stands at 63.74 million as per July 2014 estimates. Equally, Germany has the highest number of labor force (44.2 million) comparing to 30.15 million of UK labor force. In terms of unemployment rate Greece is on top of the list with 27.9 per cent while Spain is placed as second with 26.3 per cent followed by Portugal and 
Italy with 16.8 and 12.4 per cent, respectively. Yet again, Germany has the lowest unemployment rate (5.3 per cent) while unemployment rate for UK stands at 7.2 per cent.

Table 3 Selected Economic Indicators

\begin{tabular}{|l|l|l|l|l|l|l|}
\hline Country & $\begin{array}{l}\text { Population } \\
\text { (million) }\end{array}$ & $\begin{array}{l}\text { Labor force } \\
\text { (million) }\end{array}$ & $\begin{array}{l}\text { Unemployment } \\
\text { rate }\end{array}$ & $\begin{array}{l}\text { Population below } \\
\text { poverty line }\end{array}$ & $\begin{array}{l}\text { Taxes and } \\
\text { revenues }\end{array}$ & $\begin{array}{l}\text { GDP } \\
\text { growth }\end{array}$ \\
\hline Bulgaria & 6.9 & 2.55 & $11.6 \%$ & $21.8 \%(2008$ est.) & $35 \%$ & $0.5 \%$ \\
\hline France & 66.23 & 29.95 & $10.2 \%$ & $7.9 \%(2011$ est.) & $51.5 \%$ & $0.03 \%$ \\
\hline Germany & 81.00 & 44.20 & $5.3 \%$ & $15.5 \%(2010$ est.) & $45.3 \%$ & $0.5 \%$ \\
\hline Greece & 10.78 & 4.92 & $27.9 \%$ & $20 \%(2009$ est.) & $43.7 \%$ & $-3.8 \%$ \\
\hline Italy & 61.68 & 25.74 & $12.4 \%$ & $29.9 \%(2012$ est.) & $47.6 \%$ & $-1.8 \%$ \\
\hline Poland & 38.35 & 18.22 & $10.3 \%$ & $10.6 \%(2008$ est.) & $18 \%$ & $1.3 \%$ \\
\hline Portugal & 10.81 & 5.40 & $16.8 \%$ & $18 \%(2006$ est.) & $43.5 \%$ & $-1.8 \%$ \\
\hline Romania & 21.73 & 9.45 & $7.3 \%$ & $22.2 \%(2011$ est.) & $31.8 \%$ & $3.5 \%$ \\
\hline Spain & 47.74 & 23.20 & $26.3 \%$ & $21.1 \%(2012$ est.) & $37.1 \%$ & $-1.3 \%$ \\
\hline UK & 63.74 & 30.15 & $7.2 \%$ & $16.2 \%(2011$ est.) & $41.1 \%$ & $1.8 \%$ \\
\hline
\end{tabular}

Sources: Eurostat (2015).

Notes: population estimates are for the year 2014, unemployment rates taxes and other revenues (\% of GDP), and GDP growth rates are estimates of year 2013.

Italy has largest proportion of population below the poverty line 30 per cent while the lowest on the list is France with a score of about 8 per cent. France is the leading country in tax revenues followed by Italy, Germany, Greece, Portugal, and UK. In contrast, UK is the fastest growing economy in Western Europe with a GDP growth of 1.8 per cent and second in whole Europe after Romania with 3.5 per cent GDP growth. Economic indicators are discussed to highlight the factors urging people within EU to migrate to UK or other stable economies.

According to different commentators the highest inflows to the UK are from western European countries such as Portugal, Spain, and Italy. The unemployment figures explain the reason for such huge inflows. It is interesting to note that despite the recent ban implemented by the UK government on benefits schemes where any EU-resident is restricted by law from accessing government funds for first three months upon her/his entry to the UK. This suggests that the immigration trends are not subject to avail benefits but jobs.

\subsection{Immigration to the $U K$}

During the 1960s and 1970s, number of emigrants was higher than immigrants in the UK. Since late 1990s, immigration has been steadily rising, in part as a result of the recent broadening of the EU freedom of movement zone. EU immigration to the UK has dramatically increased over the past decade from 117 thousand in 2005 to 3.161 million in 2014 (see Figure 1 for historic EU immigration trends to the UK during the last decade). 
Figure 1 EU Immigration to the UK, 2005 to 2014

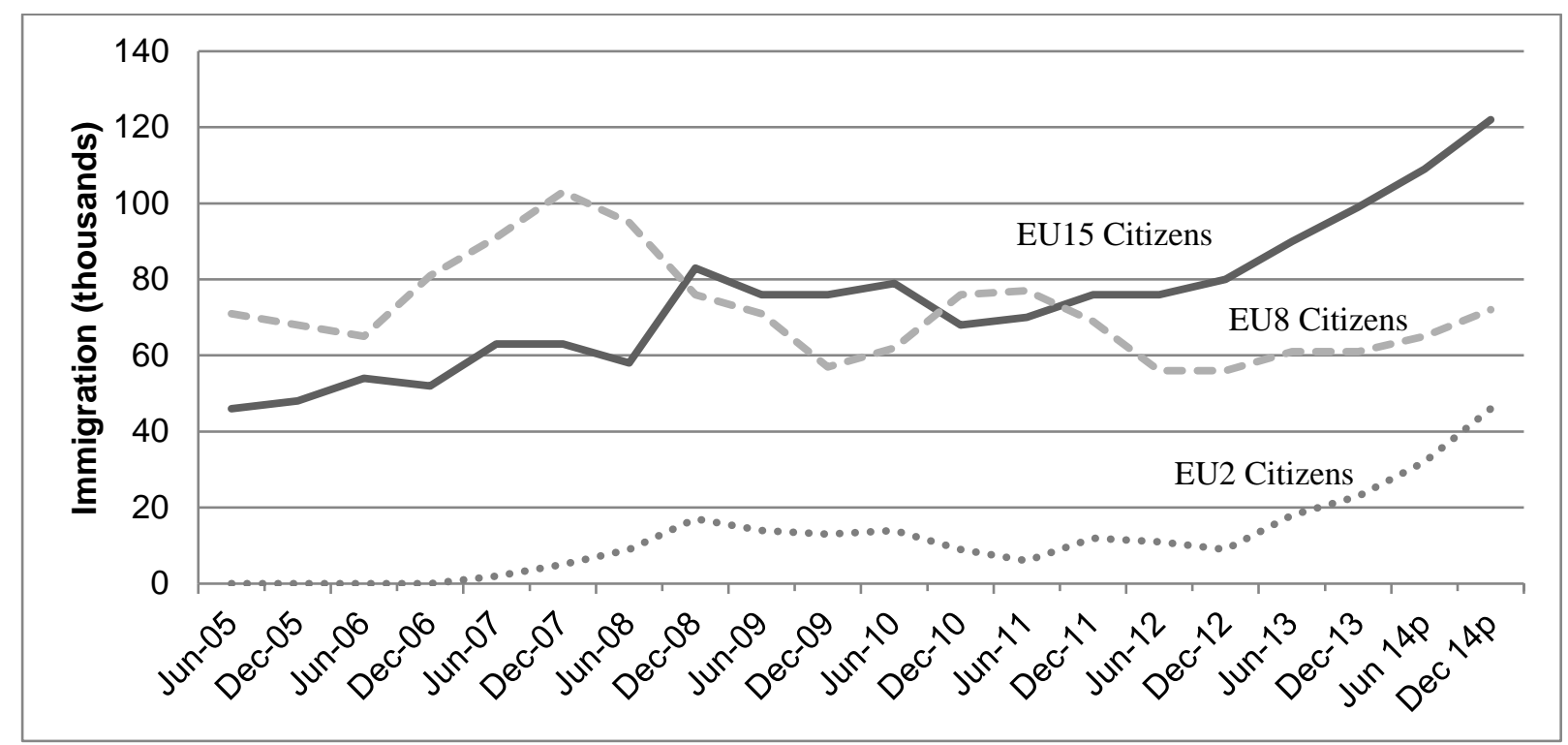

Source: Adopted from Office for National Statistics (2015).

Notes: EU15 consists of Austria, Belgium, Denmark, Finland, France, Germany, Greece, Italy, Luxembourg, Netherlands, Portugal, Republic of Ireland, Spain, Sweden and the United Kingdom. EU8 are the 8 Central and Eastern European countries that joined the EU on 1 May 2004: Czech Republic, Estonia, Hungary, Latvia, Lithuania, Poland, Slovakia and Slovenia. EU8 does not include the 2 other countries that joined on that date: Cyprus and Malta. The EU2 are the 2 countries that joined the EU on 1 January 2007: Bulgaria and Romania.

Similar trends are confirmed by the Department for Work and Pensions (2015), which is responsible for the allocation of National Insurance Number ${ }^{4}$ (NINo) for those seeking for work or claim social benefits in the UK. According to the report a total of 824 thousand NINo were allocated in 12 months to March 2015, an increase of 221 thousand (37\%) on the previous year. Fascinatingly, $76 \%$ of NINo allocations were made to the EU nationals, which accounts for the highest annual total since the reporting period began back in 2002. Breaking these figures down into recession-ravaged Western- versus poorer Eastern-European member states, the former (EU8 citizens) made up $30.27 \%$ of the total NINo allocations to the EU citizens while the latter (EU2) made up $23.19 \%$ followed by the EU8, which accounted for $20.46 \%$. Furthermore, EU countries also topped the table in terms of NINo allocations. These figures clearly indicate a huge human capital inflow into the UK.

\subsection{Data collection}

Given the research purpose of investigating the role of knowledge-resources i.e., intellectual capital in times of socio-economic distress with specific relations to Britain's social benefits schemes, various individuals with diversified ethnic and geographical backgrounds, were

\footnotetext{
${ }^{4}$ Quarterly data on NINo registrations to EU nationals is provided in appendix 1.
} 
targeted for interviews. The person criteria for interviewee were set as if she/he is: (1) living with a partner or having a family; (2) at least one of the family member is employed; and (3) the family is affiliated in any capacity with the social benefit schemes such as working tax credit scheme, unemployment (job seeker allowance), housing or child benefit allowance. The fieldwork was undertaken between May 2013 and July 2014. It should be noted that, given the person specification above, it was fairly a difficult task to reach out targeted individuals. Initially, the Hounslow Council was approached to get some initial data including the contact details but the request was refused. The participants in the present study come from diversified ethnic and geographical backgrounds. This particular area within London city (i.e. Hounslow) was selected for interviews after carefully examining the profile of inhabitants via personal visits and information available from different sources. The sampled thirty-five interviewees were non-UK nationals i.e. residents of European Union or European Economic Area.

Participants were approached through a leaflet handed over in person i.e. on social and communal gatherings, stating the purpose of the study and contact details of the researcher. Initially, a total of two hundred leaflets were hand distributed by the researcher between May and June 2013. Thirty respondents agreed for the interview, in which six participants were omitted as they do not meet the person criteria. In order to get a higher representation, 127 leaflets were further distributed mainly but sliding through doors and placing them in individual mail boxes by the researcher in December 2013. The turnover was fairly low, however, 11 individual participants agreed for interviews. Hence, the final sampled interviewees stand 35 individuals. Twenty-four interviews were conducted face-toface and the remaining eleven were telephonic interviews. The interviews lasted from 25 minutes to 45 minutes. In order to carefully transcribe the interviews to provide a basis for reliable data analysis a checklist for questions was prepared. In order to encourage the participants to express their opinions and experiences openly and freely, semi-structured questions were designed for the interviews. After each interview, the interview process was reviewed based on gained information.

The final sample comprised of 35 migrants from the Western (57\%) and Eastern (43) European countries living in the UK. Sixteen interviewees were male (46\%) while nineteen were female (54\%) with an average age of 32 years. Participants included in this study migrated to the UK with no pre-determined time frame therefore, their stay in the UK varied between 2 to 7 years. Similarly, their education also varied from high school diploma to master's degree obtained in the UK or abroad. 


\section{Empirical results}

\subsection{Relations of mutual trust}

I came to the city with no social contacts but with good education and teaching skills [...] initially, I volunteered for an organization for language swap [...] the trust thrived [...] within three months I was offered a paid job in a sister concern, an Italian language teacher.

The above quote suggests that human capital is something that rarely depreciates instead it helps individuals in making right decisions on a right time. At the same time, human intellectual capital in the form of knowledge, experience, and skills boosts confidence and improves one's credibility in social relationships. Hence, mutual trust exists when actor A (the teacher) initially volunteered for three months and proved her credibility to actor B (the organization), utilizing human capital i.e. knowledge and skills embedded in her. As Hauberer (2011) simplifies that action establishes an expectation in A and the obligation in B to justify the trust.

\subsection{Authority relations}

I have to maintain thirty-four hours of paid work per week to reap the working tax credit benefit as my partner is yet unemployed and we need this money to maintain our household. Equally, I am grateful to the HM revenues for providing this support for my family and I do not want to be a complete burden on the tax payers either. I am contributing and paying back as much as I can [...] I pay my council tax and other income tax utility bills on regular basis. Above all, I want to maintain good relationship with the council and I do not have any intention to provide any misguided or false information as it is not beneficial for my family in the longer run, a Polish retail store worker.

The above narrative suggests that migrants bring their personal intellectual capital in the form of human capital and make best use of it. They try to pay back what they get out of the system. These claims endorse the earlier findings of Dustmann and Frattini (2013), who find that immigrants from EEA have made a very sizeable net fiscal contribution in the recent decade and therefore helped to reduce the fiscal burden on UK-born workers. Hence, IC works well with control and mutually benefits all the parties involved. Equally, the statement highlights the importance of relational capital that a beneficiary feels towards the authorities 
as for survival and thriving opportunities. The above narrative also indicates the ethicality amongst migrants living in the UK.

\subsection{Informal potential}

[...] one of the things I learned in the first four weeks is that investments in social capital are too small to be preserved [...] I shared with the group, how I failed the first entry test for a retail job and got a six month ban [...] further, I advised the best techniques to take the test [...] for my surprise, an unexpected fellow approached me in a week time and recommended for my current job, a Spanish aftersales services operator.

Knowledge and experience put oneself on ease to deliver and drive information across individuals. Coleman (1988) is concerned that an actor functions as a source of information for other actors, because she/he is well informed. But because the information possessing actor only tries to maximize her/his own utility, the information is just used for her/his own advantage and is not distributed. Whereas Hauberer (2011) contends that to preserve the relationships and their information potentials, it is indispensable to share information with other actors in the social structure.

\subsection{Effective norms}

[...] There were talks about how to mislead authorities to get house benefits. It was completely unethical and irresponsible behavior to me and I could imagine the potential effects of such act are far worse on others who maybe really in need of helping hand [...] I am a mother, I have had applied for housing benefits those days but I am well educated with sufficient working experience. I witnessed that moral crisis hits people way before economic crisis and once people are in economic downturn, they tend to adopt 'me-first' policy and ignore all the norms, a French public health worker.

Yet again, intellectual ability in the form of knowledge and insight guides individuals in times of moral crisis. Hence, IC can be used as a tool to encounter with unethical behaviors. As stated in the earlier narrative of a Polish retails store worker, migrants realize their moral and ethical obligations towards the society and their personal intellectual capital helps them to maintain their status as an ethical expatriate. Another interpretation of the narrative is that migrants choose UK for its strong economic performance and better opportunities for work rather than the social benefits schemes. Such schemes are deemed helpful in a developed country like UK. 


\subsection{Appropriate social organizations}

[....] we met in an informal social environment, which helped me exchange various ideas

[....] given the continuity of such informal meetings my intuition has developed further [....] this is a good motivation to complete my novel [....] being socialized is also giving the opportunity to develop my relationship beyond geographical boundaries as well as strengthen my relationship with people around me, an Irish writer.

In pure economic terms foreign direct investment or FDI is a form of capital which foreign companies of individuals (i.e. tourists) bring into a country. Given the views above the dynamics of such relationship are also evolving. FDI is not limited to pure capital gains only, exchange and delivery of knowledge or inspiration with a warm touch of human capital is yet another constraint of the classical mind set of FDI which has been highlighted here.

While chatting with a late night customer, I was given the idea to write my thesis on waste management while taking my pizza company as a case study [....] the idea clicked when discussed with the management [....] the company waste is cut down by seventy percent since my empirical work six months ago and with the money saved from adopting best techniques to avoid extra wastage, a new soft-toyed playground has been funded by my company for community kids [....] it feels right to work for this company, a Spanish branch manager.

\subsection{Comparative analysis}

The analysis reveals that the sampled migrants living in London are well off in utilizing their knowledge-resource particularly, human capital to establish and strengthen relational capital (in this case, their relationships with the benefits provider) as well as social relationships. Furthermore, the analysis suggests that the sampled migrants crave for work rather than benefits. This finding lends support to the claims made by the OECD (2013) report which suggests that most immigrants do not come for social benefits, they come to find work and to improve their lives and those of their families.

I work seven days a week to support my four kids [....] all are students and I do not feel comfortable in the society when people know that I take some support from council [....]

I wish this period goes over soon, an Italian restaurant owner.

This is yet evidence that despite the available social support, migrants crave for work and are not completely dependent on benefits. An increase dependence on social support will result in higher natural unemployment. 
Similarly, a Latvian midwife stated that;

[...] my sister has recently finished her university back in my country [....] and now I want her to come here, given the poor economic situation in my home country [....] so that we both could work and be better off and finally I will be able to say goodbye to social help.

\subsection{Understanding of IC concept}

Given that majority of the participant were educated and compelled by their fate were working in jobs that they normally were not use to (i.e. a Spanish engineer working as a cleaner in a restaurant) nonetheless, it did not take away their education, skills, and expertise. In the last part of the interview, each interviewee was asked some question related to the concept of intellectual capital. Surprisingly, the participants were abstractly aware of the concept:

I think IC refers to the knowledge and insight that an individual possesses, a Rumanian engineer.

IC is like IQ or acumen about the social realities, a Portuguese club manager.

I have never read about intellectual capital however, in my understanding it is the use of knowledge [doesn't mean necessarily knowledge in terms of academia] for personal benefits or benefits of others, a Polish nutritionist.

I have had the concept of intangibles in my accounting lecture. So, IC is something that is invisible but it exists i.e. trust or good-will, a German financial analyst.

My mobile always keeps me updated but I never realize it is a supporting mechanism [....] thank you! I have learned something new and fresh that I will be sharing with my friends for quite some time and surfing as well over the internet, a Bulgarian chef.

The social ground seems to be fertile to sow the crop of Knowledge-eco society at least the context of knowledge rich society i.e. United Kingdom. The analysis infers that the phenomenon of intellectual capital is not limited to corporate intellectual ability to create value for its stakeholders but the concept is deeply embedded in social actors with or without their knowledge.

\subsection{Access to the dole}

The study equally aims to highlight the use of various social benefits schemes available in the UK with specific reference to the EU migrants who are accused to target UK due its lax social benefit schemes. 
As can be seen in Figure 2, sixty-four percent of the interviewees have claimed working tax credits followed by housing allowance (19\%), Job seekers allowance (9\%) and child benefits $(8 \%)$ respectively. This suggests that majority of the migrants are in low paid employment and to compensate their household expenses, they claim working tax credits. This is consistent with the earlier findings of Janta et al. (2011), who found that migrants employed in the hotel industry in the UK are on lower wages. Another interesting observation is that since one third of the migrants meet the prerequisites of claiming working tax credits (i.e. one must be employed or has worked in the UK to make this claim), this suggests that migrants come to the UK for work and not to merely claim social benefits as suggested by the earlier literature (see Boeri, 2010; Drinkwater and Robinson, 2013).

Figure 2 Migrants' use of social benefits schemes

- Child benefit $\square$ Housing benefit allowance $₫$ Job seekers allowance $₫$ Working tax credits

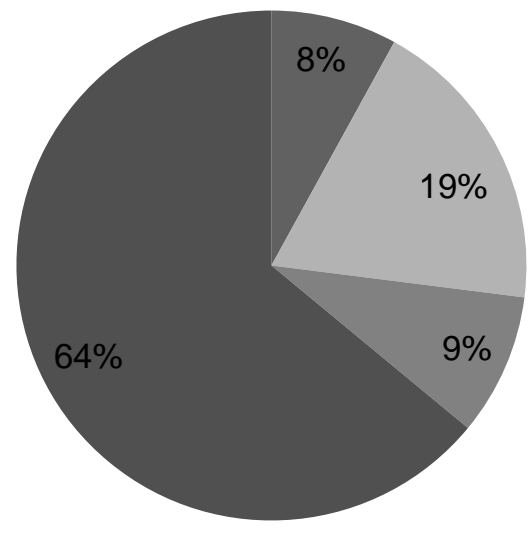

To summarize, the analysis shows that although participants were pushed by socio-economic malaise in their home countries however, social welfare system in the UK was not the main pull factor for the sampled migrants. The result of migrants' access to the social benefit schemes (specially, working tax credits) demonstrates that they are not burden on the UK welfare system as they maintain constant employment that adds value to the country economy. This challenges the views held in the previous studies that migrants rely on the welfare state (Bratsberg et al., 2014). Instead, this study through using the qualitative data provides support to the work of Dustmann and Frattini (2014) which suggest that UK continued to attract migrants (one-third from the EU) throughout the recession period and such migration surge added value to the country economy. Another interpretation of the results is that the sampled migrant workers may have been exploited by the employers as they 
are in low paid jobs and to meet the household expenditure they tend to access the social welfare schemes such as working tax credits, in particular where they are deemed eligible based on their employment status.

The analysis further suggests that during their stay in the UK, the interviewees used various forms of IC i.e. human and relational capital to learn and develop new skills that in turn helped them to survive in tough economic conditions, which ultimately added value (through continuous employment) to the economy at large. Similar findings are documented by the recent studies (see Barra and Zotti, 2016; Crescenzi et al., 2016; Erdem, 2016).

\subsection{The future}

Although the interviewees were fairly confident about their survival and thriving capabilities, they however, were quite hazy about what the future holds for them. When they were faced with the question, where do they see themselves in next 5 to 10 years, majority of the respondents highlighted the uncertainty surrounding their personal circumstances and the future economic and social environment in the UK (also see Fernando and Cohen, 2015) and their home countries.

It is the elite who failed in their games of big! gains without realizing that they are putting the future of millions of fellow global citizens on stake [....] I don't see the economic recovery anytime soon in Greece or in Europe (if that matters) [....] I am happy with my job and I can see a promising future for me and my family [....] my plan is to stay and develop further in the UK rather than going back, a Greek superstore manager.

These views were shared with some other participants. In which they considered UK economy stable comparing to one in their home countries. Participants also valued the equal job opportunities in the UK.

In (Poland), you cannot progress in your career unless you have a strong political or personal connections [....] I don't! [....] I am happy that my skills are appreciated and I can compete equally with British [....] what else do you want?

Since Europe is currently engulfed by the austerity measures and there are no signs of dramatic economic recovery in the nearer future. Such economic- and social-distress pushed may individuals to relocate to the UK. Therefore, the individuals included in this study are not considering relocation, either back to their home countries or elsewhere. At the same time given it stable economic performance with comparatively lower unemployment rate, coupled with social welfare support were the pull factors that attracted many towards the UK. 
However, the situation may change given the uncertain future of UK in the EU. That is when UK may face brain-drain as skilled workers may decide to relocate and semi-skilled or unskilled workers may find newer heavens, leaving the UK's labor workforce. This merits for future research.

\section{Conclusions}

The present study explores the role of knowledge-resources i.e. human capital from a novel prospect socio-economic setting in the context of migrants living in the UK with reference to social benefit schemes. Based on interviews with a diversified ethnic group while using the lens of social capital theory, the study reveals how knowledge-resources i.e. human intellectual capital thrives in social setting in times of socio-economic turbulence and even adds value to a country economy. The study finds that immigrants bring along various profiles of intellectual capital to the UK, which they use to generate higher revenue in the form of taxes and reap less from social benefit schemes and support programs. Hence, help to reduce the fiscal burden of the country. Equally, migrants from EU countries bring more knowledge and skills into the UK, which ultimately build and nourish a "Knowledge-eco society". At times when economies and establishments around the globe are shrinking and causing economic and social distress, it provides an equal opportunity for intellectual capital profiles, particularly human intellectual capital to flourish further. Thus, knowledge assets human capital in particular does not shrink in time of economic meltdown, instead it thrives itself equally in blue times given appropriate social settings. Hence, IC not only adds value to enterprise but to the society at large. In crux, IC can be exploited to build a strong society at times of financial distress. Therefore, the social ground seems to be fertile to sow the crop of Knowledge-eco society, in the context of knowledge rich society i.e. United Kingdom. The analysis infers that the phenomenon of intellectual capital is not limited to corporate intellectual ability to produce value for its stakeholders but the concept is deeply embedded in social actors with or without their knowledge.

This study is not without limitations. This study is based on a small group of 35 migrants from the EU living in London, who do not represent the views of the entire EU diaspora in the UK. This study however, aimed to broaden our understanding of the role of knowledge resources in the age of financial distress. Furthermore, this study has gathered evidence from one city in the UK and one country in the European Union, an important way 
forward would be to empirically examine the perceptions of EU and non-EU migrants living in the UK and in the EU to ascertain their perspective. It would also be very valuable for future research to explore the future intentions of EU migrants and this may cause a braindrain in the UK workforce. Another potential area of research is to focus on women migrants as they are more likely to migrate to acquire better career options (see Andresen et al., 2015; Napier and Taylor 2002), this needs further investigation.

\section{Acknowledgements}

I duly appreciate the critical and valuable inputs by the three anonymous referees. Sincere thanks to Professor Patricia Ordóñez de Pablos, Editor in Chief for the support.

\section{References}

Andresen, M., Biemann, T. and Marshall, M.W. (2015) 'What makes them move abroad? Reviewing and exploring differences between self-initiated and assigned expatriation', The International Journal of Human Resource Management, Vol. 26, No. 7, pp. 932947.

Barra, C. and Zotti, R. (2016) 'Investigating the Human Capital Development-growth Nexus Does the Efficiency of Universities Matter?, International Regional Science Review, doi: $10.1177 / 0160017615626215$.

Benhabib, J. and Spiegel, M.M. (1994) 'The role of human capital in economic development evidence from aggregate cross-country data', Journal of Monetary Economics, Vol. 34, No. 2, pp. 143-173.

Boeri, T. (2010) 'Immigration to the Land of Redistribution', Economica, Vol. 77, No. 308, pp. 651-687.

Bontis, N. (2001) 'Assessing knowledge assets: a review of the models used to measure intellectual capital', International Journal of Management Reviews, Vol. 3, No. 1, pp. 41-60.

Bourdieu, P. (1986) 'The forms of capital', in Handbook of Theory and Research for the Sociology of Education, edited by J. Richardson, New York: Greenwood pp. 241-258.

Bratsberg, B., Raaum, O. and Roed, K. (2014) 'Immigrants, labour market performance, and social insurance', Economic Journal, Vol. 124, No. 580, pp. 644-83. 
Brooking, A. (1996) Intellectual capital: Core Asset for the Third Millennium Enterprise. London: Thomson Business Press.

Bueno, E., Salmador M. P., and Óscar R. (2004) 'The role of social capital in today's economy: empirical evidence and proposal of a new model of intellectual capital', Journal of Intellectual Capital, Vol 5, No. 4, pp. 556-574.

Camuffo, A. and Comacchio, A. (2005) 'Linking intellectual capital and competitive advantage: A cross-firm competence model for north-east Italian SMEs in the manufacturing industry', Human Resource Development International, Vol. 8, No.3, pp. 361-377.

Chang, S. L. (2007) Valuing intellectual capital and firms' performance: modifying value added intellectual coefficient (VAICTM) in Taiwan IT industry, Golden Gate University, San Francisco, CA.

Clarke, J. and Newman, J. (2012) 'The alchemy of austerity', Critical Social Policy, Vol. 32, No. 3, pp. 299-319.

Coleman, J. S. (1988) 'Social capital in the creation of human capital', American Journal of Sociology, pp. 95-120.

Campello, M., Graham, J. R., \& Harvey, C. R. (2010) 'The real effects of financial constraints: Evidence from a financial crisis', Journal of Financial Economics, Vol. 97, No. 3, pp. 470-487.

Crane, L., Bontis, N. and Chase, R. (2014) 'Trouble with tacit: developing a new perspective and approach', Journal of Knowledge Management, Vol. 18, No. 6, pp. 1127-1140.

Crescenzi, R., Luca, D. and Milio, S. (2016) 'The geography of the economic crisis in Europe: national macroeconomic conditions, regional structural factors and short-term economic performance', Cambridge Journal of Regions, Economy and Society, doi: 10.1093/cjres/rsv031.

Curado, C. (2008) 'Perceptions of knowledge management and intellectual capital in the banking industry', Journal of Knowledge Management, Vol. 12, No. 3, pp. 141-155.

Davies, P.M.C. (1967) 'The Tacit Dimension', Philosophical Studies, 17, pp.222-234.

Department for Work \& Pensions (2015) National Insurance Number Allocations to Adult Overseas Nationals: Quarterly Report-Registrations to March 2015. Available online at:https://www.gov.uk/government/uploads/system/uploads/attachment_data/file/4282 50/nino-allocations-to_Mar-2015.pdf [Accessed 3 February 2016].

Drinkwater, S. and Robinson, C. (2013) 'Welfare participation by immigrants in the UK', International Journal of Manpower, Vol. 34, No. 2, pp. 100-12. 
Dumay, J. and Garanina, T. (2013) 'Intellectual capital research: a critical examination of the third stage', Journal of Intellectual Capital, Vol. 14, No. 1, pp.10-25.

Dustmann, C. and Frattini, T. (2014) 'The fiscal effects of immigration to the UK." The Economic Journal, Vol.124, No. 580, pp. 593-643.

Edvinsson, L. and Malone M. S. (1997) Intellectual Capital: Realizing Your Company's True Value by Finding Its Hidden Roots. New York: Harper Collins Publishers, Inc.

Erdem, U. (2016) 'Regional human capital distribution and disparities in Turkey', Review of Urban \& Regional Development Studies, Vol. 28, No. 2, pp. 1-16.

Eurostat (2015) Euro area unemployment rate. Available online at:http://ec.europa.eu/eurostat/documents/2995521/6862104/3-03062015-BP EN.pdf/efc97561-fad1-4e10-b6c1-e1c80e2bb582. [Accessed 1 February 2016].

Goh, P.C. (2005) 'Intellectual capital performance of commercial banks in Malaysia', Journal of Intellectual Capital, Vol. 6, No.3, pp. 385-396.

Guthrie, J., Ricceri, F. and Dumay, J. (2012) 'Reflections and projections: a decade of intellectual capital accounting research', The British Accounting Review, Vol. 44, No. 2, pp. 68-82.

Häuberer, J. (2011) Social Capital Theory: Springer.

Hermans, R. and Kauranen, I. (2005) 'Value creation potential of intellectual capital in biotechnology-empirical evidence from Finland', $R \& D$ Management, Vol. 35, No.2, pp. 171-185.

Howden, D. (2011) 'Europe's unemployment crisis: Some hidden relief?, Institutions in Crisis: European Perspectives on the Recession. Cheltenham, UK and Northampton, MA: Edward Elgar, pp. 56-75.

Hsu, L. C., and Wang, C-H. (2012) 'Clarifying the effect of intellectual capital on performance: the mediating role of dynamic capability', British Journal of Management, Vol. 23, No. 2, pp. 179-205.

Hudson, W. J. (1993) Intellectual capital: How to build it, enhance it, use it: J. Wiley.

Hussi, T. (2004) 'Reconfiguring knowledge management-combining intellectual capital, intangible assets and knowledge creation', Journal of Knowledge Management, Vol. 8, No. 2, pp. 36-52.

Janta, H., Ladkin, A., Brown, L. and Lugosi, P. (2011) 'Employment experiences of Polish migrant workers in the UK hospitality sector', Tourism Management, Vol. 32, No. 5, pp.1006-1019. 
Kamath, G. B. (2007) 'The intellectual capital performance of the Indian banking sector', Journal of Intellectual Capital, Vol. 8, No. 1, pp. 96-123.

Käpylä, J., Kujansivu, P. and Lönnqvist, A. (2012) 'National intellectual capital performance: a strategic approach', Journal of Intellectual Capital, Vol. 13, No. 3, pp. 343-362.

Kennedy, S. (2011) The Habitual Residence Test, House of Commons Library Standard Note SN/SP/416. London: House of Commons.

King, R. (2012) Theories and typologies of migration: an overview and a primer: 1-43.

Liebig, T. and Mo, J. (2013) 'The fiscal impact of immigration in OECD countries', chapter 3, in (OECD, ed.), International Migration Outlook 2013, pp. 125-89, Paris: OECD Publishing.

Martínez-Torres, M. R. (2006) 'A procedure to design a structural and measurement model of intellectual capital: an exploratory study', Information \& Management, Vol. 43, No. 5, pp. 617-626.

Massingham, P.R. and Chase, R. (2014) 'An evaluation of knowledge management tools: Part 1-Managing knowledge resources', Journal of Knowledge Management, Vol. 18, No. 6, pp. 1075-1100.

Mavridis, D.G. (2004) 'The intellectual capital performance of the Japanese banking sector', Journal of Intellectual Capital, Vol. 5, No. 1, pp. 92-115.

McConnachie, G. (1997) 'The management of intellectual assets: delivering value to the business', Journal of Knowledge Management, Vol. 1, No. 1, pp. 56-62.

Mention, A-L. and Bontis, N. (2013) 'Intellectual capital and performance within the banking sector of Luxembourg and Belgium', Journal of Intellectual Capital, Vol. 14, No. 2 , pp. 286-309.

Manacorda, M., Manning, A. and Wadsworth, J. (2012) 'The impact of immigration on the structure of wages: Theory and evidence from Britain', Journal of the European Economic Association, Vol. 10, No. 1, pp.120-151.

Murthy, V. and Mouritsen, J. (2011) 'The performance of intellectual capital: mobilising relationships between intellectual and financial capital in a bank', Accounting, Auditing \& Accountability Journal, Vol. 24, No.5, pp. 622-646.

Napier, N.K., and Taylor, S. (2002) 'Experiences of women professionals abroad: comparisons across Japan, China and Turkey', International Journal of Human Resource Management, Vol. 13, No. 5, pp. 837-851.

Nahapiet, J. and Ghoshal, S. (1998) 'Social capital, intellectual capital, and the organizational advantage', Academy of Management Review, Vol. 23, No. 1, pp. 242-266. 
Nawaz, T. (2015) Ethical Banking in the Land of Redistributive Policies, Scholars Press.

Nawaz, T. and Goj, T. (2013) 'Intellectual Capital: A Synthesis of Current Research with Special Reference to Islamic Banking and Finance', International Journal of Business and Management Studies, Vol. 2, No. 1, pp. 303-317.

Nonaka, I. and Takeuchi, H. (1995) The knowledge-creating company: How Japanese companies create the dynamics of innovation: Oxford university press.

OECD. 2013. International Migration Outlook 2013. Paris.

Ordonez de Pablos, P. (2003) 'Intellectual capital reporting in Spain: a comparative view', Journal of Intellectual Capital, Vol. 4, No. 1, pp. 61-81.

Ottaviano, G. I. and Peri, G. (2012) 'Rethinking the effect of immigration on wages', Journal of the European Economic Association, Vol. 10, No. 1, pp. 152-197.

Pal, K. and Soriya, S. (2012) 'IC performance of Indian pharmaceutical and textile industry', Journal of Intellectual Capital, Vol. 13, No. 1, pp. 120-137.

Peet, R. (2011) 'Inequality, crisis and austerity in finance capitalism', Cambridge Journal of Regions, Economy and Society, Vol. 4, No. 3, pp. 383-399.

Ponticelli J and Voth H-J (2011) 'Austerity and Anarchy: Budget Cuts and Social Unrest in Europe, 1919-2009', Discussion Paper Series No. 8513. Centre for Economic Policy Research.

Rowthorn, R. (2008) 'The fiscal impact of immigration on the advanced economies', Oxford Review of Economic Policy, Vol. 24, No. 3, pp.560-580.

Rudež, H.N. and Mihalič, T. (2007) 'Intellectual capital in the hotel industry: A case study from Slovenia', International Journal of Hospitality Management, Vol. 26, No. 1, pp. 88-199.

Rylander, A., Jacobsen, K. and Roos, G. (2000) 'Towards improved information disclosure on intellectual capital', International Journal of Technology Management, Vol. 20, No. 5, pp. 715-741.

Seleim, A., Ashour, A. and Bontis, N. (2007) 'Human capital and organizational performance: a study of Egyptian software companies', Management Decision, Vol. 45, No. 4, pp. 789-801.

Sharabati, A.A., Jawad, S. N. and Bontis, N. (2010) 'Intellectual capital and business performance in the pharmaceutical sector of Jordan', Management Decision, Vol. 48, No. 1, pp. 105-131.

Stahle, P. and Hong, J. (2002) 'Dynamic intellectual capital in global rapidly changing industries', Journal of Knowledge Management, Vol. 6, No. 2, pp. 177-189. 
Stewart, T. and Ruckdeschel, C. (1998) Intellectual capital: The new wealth of organizations. Wiley Online Library.

Sullivan, P.H. (1999) 'Profiting from intellectual capital', Journal of Knowledge Management, Vol. 3, No. 2, pp. 132-143.

Sveby, K. E. (2007) Methods for measuring intangible assets www.sveiby.com.au/bookcontents.html

Sveiby, K.E. (1997) The new organizational wealth: Managing \& measuring knowledgebased assets: Berrett-Koehler Publishers.

Teece, D.J. (1998) 'Capturing Value from Knowledge Assets: the new economy, markets for know-how, and intagible assets', California Management Review, Vol. 40, No. 3, pp. $35-54$.

Tseng, C-Y. and Goo Y.J. (2005) 'Intellectual capital and corporate value in an emerging economy: empirical study of Taiwanese manufacturers', $R \& D$ Management, Vol. 35, No. 2, pp. 187-201.

Taylor-Gooby, P. and Stoker, G. (2011) 'The Coalition Programme: A New Vision for Britain or Politics as Usual?, The Political Quarterly, Vol. 82, No. 1, pp. 4-15.

Wang, W-Y. and Chang, C. (2005) 'Intellectual capital and performance in causal models: evidence from the information technology industry in Taiwan', Journal of Intellectual Capital, Vol. 6, No. 2, pp. 222-236.

Youndt, M.A., Subramaniam, M. and Snell, S.A. (2004) 'Intellectual Capital Profiles: An Examination of Investments and Returns', Journal of Management Studies, Vol. 41, No. 2, pp. 335-361. 


\section{Appendices}

Appendix 1 Nation Insurance Number (NINo) Quarterly Registrations to EU Nationals

\begin{tabular}{|c|c|c|c|c|c|}
\hline & \multicolumn{5}{|c|}{ European Union } \\
\hline & Total & EU15 & EU8 & $E U 2$ & EU Other \\
\hline Jan-05 to Mar-05 & 138,421 & 23,180 & 46,127 & 1,635 & 557 \\
\hline Apr-05 to Jun-05 & 149,991 & 23,370 & 55,587 & 1,571 & 507 \\
\hline Jul-05 to Sep-05 & 171,422 & 23,483 & 69,933 & 1,674 & 512 \\
\hline Oct-05 to Dec-05 & 158,859 & 24,143 & 64,781 & 1,223 & 556 \\
\hline Jan-06 to Mar-06 & 182,906 & 26,836 & 78,978 & 1,238 & 606 \\
\hline Apr-06 to Jun-06 & 133,899 & 19,790 & 56,261 & 997 & 408 \\
\hline Jul-06 to Sep-06 & 151,521 & 20,245 & 69,501 & 966 & 410 \\
\hline Oct-06 to Dec-06 & 164,615 & 25,268 & 71,709 & 1,178 & 542 \\
\hline Jan-07 to Mar-07 & 255,769 & 37,432 & 111,431 & 3,699 & 774 \\
\hline Apr-07 to Jun-07 & 166,187 & 23,418 & 67,180 & 8,478 & 422 \\
\hline Jul-07 to Sep-07 & 189,939 & 24,124 & 85,553 & 11,336 & 481 \\
\hline Oct-07 to Dec-07 & 185,194 & 29,458 & 70,461 & 7,909 & 590 \\
\hline Jan-08 to Mar-08 & 191,957 & 30,465 & 70,671 & 9,200 & 667 \\
\hline Apr-08 to Jun-08 & 175,604 & 27,539 & 61,569 & 11,160 & 570 \\
\hline Jul-08 to Sep-08 & 167,316 & 26,385 & 62,498 & 12,630 & 501 \\
\hline Oct-08 to Dec-08 & 134,776 & 25,615 & 36,141 & 6,369 & 558 \\
\hline Jan-09 to Mar-09 & 208,466 & 40,586 & 54,862 & 9,806 & 798 \\
\hline Apr-09 to Jun-09 & 117,760 & 20,584 & 32,154 & 7,308 & 318 \\
\hline Jul-09 to Sep-09 & 154,544 & 24,360 & 51,902 & 11,751 & 399 \\
\hline Oct-09 to Dec-09 & 132,470 & 20,456 & 28,714 & 4,749 & 361 \\
\hline Jan-10 to Mar-10 & 168,041 & 25,935 & 38,550 & 6,393 & 427 \\
\hline Apr-10 to Jun-10 & 149,287 & 26,741 & 37,715 & 5,925 & 432 \\
\hline Jul-10 to Sep-10 & 173,580 & 30,575 & 55,907 & 11,979 & 482 \\
\hline Oct-10 to Dec-10 & 176,576 & 33,530 & 44,653 & 7,102 & 603 \\
\hline Jan-11 to Mar-11 & 205,500 & 44,097 & 48,578 & 10,918 & 630 \\
\hline Apr-11 to Jun-11 & 132,949 & 25,787 & 31,509 & 9,124 & 349 \\
\hline Jul-11 to Sep-11 & 175,513 & 35,595 & 57,930 & 12,529 & 458 \\
\hline Oct-11 to Dec-11 & 157,256 & 42,345 & 43,958 & 7,707 & 654 \\
\hline Jan-12 to Mar-12 & 135,236 & 40,128 & 35,544 & 6,211 & 506 \\
\hline Apr-12 to Jun-12 & 120,737 & 35,937 & 35,244 & 7,138 & 410 \\
\hline Jul-12 to Sep-12 & 123,590 & 31,905 & 48,193 & 6,808 & 406 \\
\hline Oct-12 to Dec-12 & 139,390 & 45,090 & 42,472 & 5,872 & 698 \\
\hline Jan-13 to Mar-13 & 178,372 & 63,123 & 52,910 & 8,400 & 828 \\
\hline Apr-13 to Jun-13 & 131,525 & 44,015 & 40,118 & 6,594 & 589 \\
\hline Jul-13 to Sep-13 & 148,389 & 44,384 & 58,011 & 7,747 & 645 \\
\hline Oct-13 to Dec-13 & 158,953 & 56,083 & 50,604 & 4,957 & 1,000 \\
\hline Jan-14 to Mar-14 & 164,432 & 45,916 & 33,071 & 45,622 & 710 \\
\hline Apr-14 to Jun-14 & 93,945 & 25,350 & 19,364 & 26,695 & 417 \\
\hline Jul-14 to Sep-14 & 250,187 & 69,255 & 66,562 & 58,108 & 1,055 \\
\hline Oct-14 to Dec-14 & 259,200 & 76,468 & 63,579 & 56,935 & 1,311 \\
\hline Jan-15 to Mar-15 & 220,825 & 66,842 & 45,177 & 51,200 & 1,095 \\
\hline
\end{tabular}

Source: Department for Work and Pensions (2015). 
Appendix 2 Unemployment Rate in EU from 2005 to 2014

\begin{tabular}{|c|c|c|c|c|c|c|c|c|c|c|}
\hline GEO/TIME & 2005 & 2006 & 2007 & 2008 & 2009 & 2010 & 2011 & 2012 & 2013 & 2014 \\
\hline $\begin{array}{l}\text { European Union } \\
\text { ( } 28 \text { countries) }\end{array}$ & 9.0 & 8.2 & 7.2 & 7.0 & 9.0 & 9.6 & 9.7 & 10.5 & 10.9 & 10.2 \\
\hline Austria & 5.6 & 5.3 & 4.9 & 4.1 & 5.3 & 4.8 & 4.6 & 4.9 & 5.4 & 5.6 \\
\hline Belgium & 8.5 & 8.3 & 7.5 & 7.0 & 7.9 & 8.3 & 7.2 & 7.6 & 8.4 & 8.5 \\
\hline Bulgaria & 10.1 & 9.0 & 6.9 & 5.6 & 6.8 & 10.3 & 11.3 & 12.3 & 13.0 & 11.4 \\
\hline Croatia & 13.0 & 11.6 & 9.9 & 8.6 & 9.2 & 11.7 & 13.7 & 16.0 & 17.3 & 17.3 \\
\hline Cyprus & 5.3 & 4.6 & 3.9 & 3.7 & 5.4 & 6.3 & 7.9 & 11.9 & 15.9 & 16.1 \\
\hline Czech Republic & 7.9 & 7.1 & 5.3 & 4.4 & 6.7 & 7.3 & 6.7 & 7.0 & 7.0 & 6.1 \\
\hline Denmark & 4.8 & 3.9 & 3.8 & 3.4 & 6.0 & 7.5 & 7.6 & 7.5 & 7.0 & 6.6 \\
\hline Estonia & 8.0 & 5.9 & 4.6 & 5.5 & 13.5 & 16.7 & 12.3 & 10.0 & 8.6 & 7.4 \\
\hline Finland & 8.4 & 7.7 & 6.9 & 6.4 & 8.2 & 8.4 & 7.8 & 7.7 & 8.2 & 8.7 \\
\hline France & 8.9 & 8.8 & 8.0 & 7.4 & 9.1 & 9.3 & 9.1 & 9.8 & 10.2 & 10.2 \\
\hline Germany & 11.2 & 10.1 & 8.5 & 7.4 & 7.6 & 7.0 & 5.8 & 5.4 & 5.2 & 5.0 \\
\hline Greece & 10.0 & 9.0 & 8.4 & 7.8 & 9.6 & 12.7 & 17.9 & 24.5 & 27.5 & 26.5 \\
\hline Hungary & 7.2 & 7.5 & 7.4 & 7.8 & 10.0 & 11.2 & 11.0 & 11.0 & 10.2 & 7.7 \\
\hline Ireland & 4.4 & 4.5 & 4.7 & 6.4 & 12.0 & 13.9 & 14.7 & 14.7 & 13.1 & 11.3 \\
\hline Italy & 7.7 & 6.8 & 6.1 & 6.7 & 7.7 & 8.4 & 8.4 & 10.7 & 12.1 & 12.7 \\
\hline Latvia & 10.0 & 7.0 & 6.1 & 7.7 & 17.5 & 19.5 & 16.2 & 15.0 & 11.9 & 10.8 \\
\hline Lithuania & 8.3 & 5.8 & 4.3 & 5.8 & 13.8 & 17.8 & 15.4 & 13.4 & 11.8 & 10.7 \\
\hline Luxembourg & 4.6 & 4.6 & 4.2 & 4.9 & 5.1 & 4.6 & 4.8 & 5.1 & 5.9 & 6.0 \\
\hline Malta & 6.9 & 6.8 & 6.5 & 6.0 & 6.9 & 6.9 & 6.4 & 6.3 & 6.4 & 5.9 \\
\hline Netherlands & 5.9 & 5.0 & 4.2 & 3.7 & 4.4 & 5.0 & 5.0 & 5.8 & 7.3 & 7.4 \\
\hline Poland & 17.9 & 13.9 & 9.6 & 7.1 & 8.1 & 9.7 & 9.7 & 10.1 & 10.3 & 9.0 \\
\hline Portugal & 8.8 & 8.9 & 9.1 & 8.8 & 10.7 & 12.0 & 12.9 & 15.8 & 16.4 & 14.1 \\
\hline Romania & 7.1 & 7.2 & 6.4 & 5.6 & 6.5 & 7.0 & 7.2 & 6.8 & 7.1 & 6.8 \\
\hline Slovakia & 16.4 & 13.5 & 11.2 & 9.6 & 12.1 & 14.5 & 13.7 & 14.0 & 14.2 & 13.2 \\
\hline Slovenia & 6.5 & 6.0 & 4.9 & 4.4 & 5.9 & 7.3 & 8.2 & 8.9 & 10.1 & 9.7 \\
\hline Spain & 9.2 & 8.5 & 8.2 & 11.3 & 17.9 & 19.9 & 21.4 & 24.8 & 26.1 & 24.5 \\
\hline Sweden & 7.7 & 7.1 & 6.1 & 6.2 & 8.3 & 8.6 & 7.8 & 8.0 & 8.0 & 7.9 \\
\hline United Kingdom & 4.8 & 5.4 & 5.3 & 5.6 & 7.6 & 7.8 & 8.1 & 7.9 & 7.6 & 6.1 \\
\hline
\end{tabular}

Source: Eurostat (2015). 